\title{
The Cultural Duality between Coastal Fortifications and the Sea
}

\author{
Giacinto Taibi a ${ }^{\text {, Rita Valenti }}{ }^{\mathrm{b}}$, Mariangela Liuzzo ${ }^{\mathrm{c}}$, Tiziana Patanè ${ }^{\mathrm{d}}$ \\ ${ }^{a}$ Struttura Didattica di Architettura - Università degli Studi di Catania, Syracuse, Italy, giacinto.taibi@gmail.com \\ ${ }^{\text {b }}$ Struttura Didattica di Architettura - Università degli Studi di Catania, Syracuse, Italy, r.valenti@unict.it \\ ${ }^{\text {c }}$ Facoltà di Ingegneria e Architettura, Università degli Studi di Enna Kore, Enna, Italy, mariangela.liuzzo@unikore.it \\ ${ }^{\mathrm{d}}$ Struttura Didattica di Architettura - Università degli Studi di Catania, Syracuse, Italy, patane.tiziana@email.it
}

\begin{abstract}
Sicily's coasts are studded with fortifications, a few which are still intact and serve as a testimony of the island's thousand year old history. Their original function of defence and control was closely linked to aspects of formality and strategic positioning in the Mediterranean. For this reason, they once constituted strong holds on the territory and represented important elements of symbolic connotations. They have been transformed through the centuries, by man's actions as well as natural occurrences, and have therefore lost their original significance. Regardless of this fact, they are still capable of giving a strong sense of identity to the topos and of recognition to the collective imagination.

The fortifications' emerging masses seem tightly linked to the cliff and the sweeping expanse of the sea which have the duty, still today, of evoking the identifying character of the area. The grandeur of the fortified walls speaks to the vastness of the sea and the depths of the abysses. The material and chromatic aspects of the stones, in contrast with the transparency of the water, tend to melt, taking on qualities of agility and sculptural composition. These aspects take on an identity of their own to the point of affecting the surfaces of the walls, highlighting the more rugged and uneven edges while softening those that are smoother.

The three castles of Syracuse, Catania, and Aci are clear examples of unique systems that are environmentally integrated and interrelated with each other because of their peculiarity.
\end{abstract}

Keywords: Mediterranean, Sicilian castles, natural-anthropic landscape, historical identity.

\section{Introduction}

We cannot help but to become emotionally involved when observing nature and its surrounding landscape, as it pervades our most internal selves. It leads us meanderingly through new and limitless realities, made real through unique aspects and peculiarities ${ }^{1}$. There is no doubt that the fortifications are an essential and significantly identifying part of the landscape.

With reference to the words of Gazzola, "the castle, more than any other monument, is connected to the land, for the material with which it is built, and is incorporated into the landscape, into the nature that surrounds it". 2

Maniace Castle in Ortigia, Ursino Castle in Catania and Castle of Aci Castello, along the Ionian Sea coast, all have been conceived as castles that overlook the sea (Fig. 1). These castles have a decisive emerging character which garners strength in its reflection in the water.

The sustainable development of these locations comes from knowledge. It is an accurate "survey drawing" that defines and constitutes a strong 
beckoning of memories. With this in mind, the reading of a fortification has to be capable of a dynamic assimilation. One that allows the user to supply it with a logical contribution that is anything but insignificant.

We need to therefore understand that we must acquire a method to correctly see and understand the significance of the fortifications, as one learns how to read a book and understand its content and meaning. The aim of the research is, therefore, to find those character values that identify that fortification in its context. In this sense, the methodological approach aims through surveys, multidisciplinary readings and historical iconography- to establish an open dialogue with the identifying characteristics, even current ones, of that defensive structure.

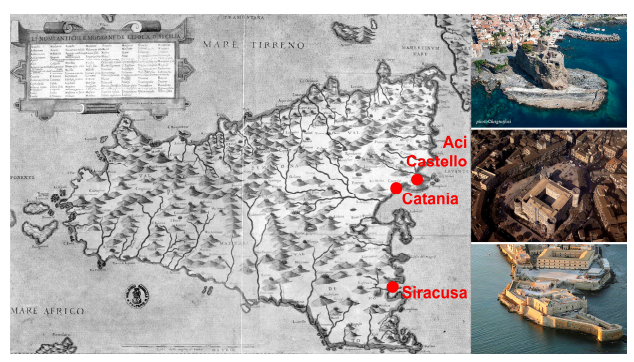

Fig. 1. Maniace Castle, Ursino Castle, Castle of Aci. Geographical localisation on Ferdinando Bertelli's map of Sicily, end of the sixteenth century (Dufour L., La Gumina A. (1998). Imago Siciliae. Cartografia storica della Sicilia 1420-1860. Sanfilippo Ed. Catania. p. 98).

\section{Maniace Castle, an integrated landscape between topos and architecture}

"On the most extreme point of the Island, stretching out towards the sea, seemingly sinking its roots into it, rises the Maniace Castle with its weighty size. One of the strongest symbols of a city that serves almost as a ring which links the ancient to the modern" (Voza, 1994, p. 148).

In the memory of those who come from Syracuse, the Maniace Castle represents a type of spatial-temporal balance in sync with the territory, in which it is located, and with the sea, which surrounds it. Within it, the manmade materials, which make up its architecture, interpret the geodynamics of the natural elements that beat against it and affect the solid mass of the building.



Fig. 2. Plan and axonometric view of the Castle of Syracuse, 1640 (Negro, Ventimiglia, 1640, pp. 109-110).

It occupies the southern point of the island of Ortigia, and together with the fortification system, constitutes a landscape continuum with the geo-morphology of the location (Fig. 2). The castle has preserved the signs of the Frederician building actions ${ }^{3}$ and presents a strict emerging geometric structure, noted also in its most ancient description "Its author, a French travelling baron lands in Syracuse during his return from the Holy Land. Like a good soldier, he observed and duly noted the main characteristics of the site as well as of the fortification: "[...] Sur l'entrée de lequelle/ cipté de SAREGOSSE/ qui vient pour mer, ha ung tres beau chasteau, hors de leditte cipté un triet de pierre, nommé TERMENIAIG, et est quairé; en chacun quayré une tour reonde; le mer le va autour" (Zorić, 1995, p. 409 ; Seigneur de Caumont Nompar, 1858).

The representation of the city of Syracuse in the xypograph of 1483, entitled Siracusa citta nella Isola de Cicilia, the "first known representation till now", as noted by Dufour (Beneventano del Bosco 1995,36$)^{4}$, highlights the castle's position on the extremity of the peninsula. This has a shape that cannot possibly correspond to the reality of what is built, and is "obviously referring to a written description" as Dufour himself hypothesised. Nevertheless, the castle has a geometrically standard structure which is inserted into the urban landscape, where the fortification complex outlines and encloses all the landscape which interacts with the sea. The close relationship between the natural setting and the castle is evident in the historical mapping that, from Vincent Mirabella's seventeenth century etchings, present the Maniace castle as a recurring element of the landscape, regardless of the final intentions of the map itself. 


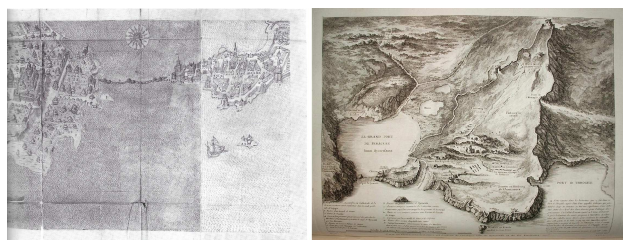

Fig. 3. Left: Vincenzo Mirabella, L'Antiche Siracuse di D. Vincenzo Mirabella e Alagona dedicate alla S.C.R.M. del re Filippo III Nostro Signore, ed. Naples 1613, Etching, 38x52 cm. Right: from a drawing by Chatelet in R. de Saint-Non, Voyage pittoresque de Naples et de Sicile, t. IV, Paris 1781-86, tav. 109, Etching, $29 \times 38 \mathrm{~cm}$.

For instance, in Mirabella's nine tables from Antiche Siracuse (ed. of 1613) ${ }^{5}$, the castle is positioned in the centre of the table, standing out with respect to the other buildings (Fig. 3).

In all of the representations of a fortified city, the symbol of the surrounding wall can not be separated from the standard geometry of the castle, which is an integral element of the anthropized landscape. The castle characterises the landscape of Ortigia even when the representation, at times, chooses to focus on the ancient Greek site, through the remains of its monuments ${ }^{6}$ which are in a location where the natural elements are predominant. The castle in this setting is illustrated as a large "rock", with no walls.

Eighteenth century travellers, searching for the classical world and famous Greek Syracuse, tended to "document" in great detail the ancientness of the location rather than the castle, even if they were familiar with Mirabella's maps. Yet previously, in 1672, Albert Jouvin de Rochefort describes the castle like this, "the most curious thing in Syracuse is the Castle which occupies a cliff separated from the sea by a large moat" (Pagello, 2004, p. 169).

The author in this quote can not avoid identifying the close relationship between architectural artefact and nature, between the castle and the rock from which it emerges. These two identities are closely related, even if the first was born out of the skilful workmanship of "master masonries" and the second is nature's work of art.
The characterising geomorphology of the site reveals the Frederician work of art that inserts itself with continuity even though it draws from the Euclidean geometry, which is known for its rational rigor which does not represent natural shapes. It is a complex artificial system that has a relationship of coherence with the landscape. It is not simply supported by the natural system, it is shaped from it. The pseudoisodomum wall building technique is not found in other constructions of the same period (Zorić, 1995, p. 410), of the same importance for impressiveness and function, such as the Ursino Castle of Catania and the Castle of Augusta (Voza, 1994). In the artistic depictions of the city, during the first half of the nineteen century, the representations of the castle place particular attention on the orography of the site and on the defensive structures whose construction, started in the sixteenth century and continued for three centuries, defined the continued transformations and additions, undermining the original Frederician structure. Today, in fact, the architectural work of the Maniace castle, when seen from the sea, presents itself in all its splendour, as an integrated system between a constructed environment and one that is natural. It leaves behind questions on its original use which has been, without a doubt, converted over the centuries towards defensive uses that "have not been able to alter the completed, structured harmony of the squared compact mass with its cylindrical towers on the corners" (Voza, 1994, p. 150). This compact mass has a continued chromatic dialogue with the forces of nature that surround and enclose it (Fig. 4).

\section{Ursino Castle, a palimpsest of a millennium history}

The architecture of the Ursino Castle of Catania, whose technical, constructive and shape characteristics have defined all of the Frederician military architecture, illustrates a blending between the technical experience of the Cistercian masters with the construction of their own abbeys. It is a sapientia construendi whose beauty was reached through the architectural expression of lines, masses and space. 


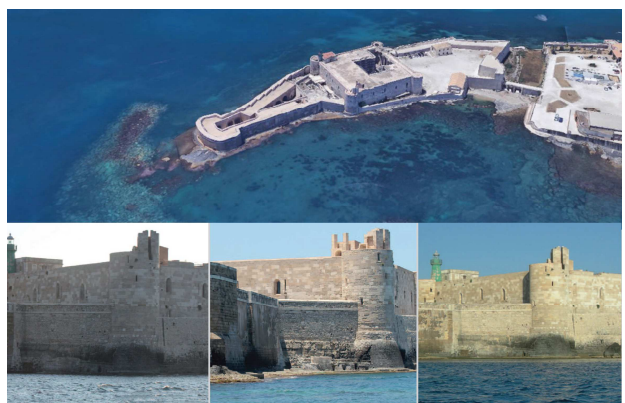

Fig. 4. Maniace Castle, Ortigia (Above: Google Earth image. Below: photos of the Laboratory of Representation, Syracuse, University of Catania).

The Castle became a military headquarter, prison and barracks towards the end of the fifteenth century when it lost its use as a royal location. Not until the first part of the twentieth century did the castle become the location of the Civic Museum.

The architecture is sober, unadorned, of simple and majestic proportions that knew how to adapt with flexibility to the local traditions. Even more so though, it was able to adapt to the natural context which surrounded it.

The name most likely refers to Castrum Sinus, or rather, the Castle on the Gulf, because in fact, Ursino Castle used to look out over the sea to defend the city and the port from its domineering position on the southern promontory. Its reflection on the water added to the castle's majesty and was able to transmit the empire's strength and greatness. Up until the end of the first half of the sixteenth century, the southern side of the castle was in close proximity to the beach and the waters of the Ionian coast. The first distancing from the sea took place during the completion of the San Giorgio bastion and the Santa Croce platform (Fig. 5).

The volcanic lava flow of 1669 definitively distanced the castle from the sea and raised the level of the surrounding land. Catania was reached by over two miles of lava flow which assaulted various parts of the city wall, filling up the valley which surrounded the castle, surpassing the height of the promontory. In the end, it settled on the Frederician fortress, definitively severing its relationship with the sea which was at this point hundreds of meters away. Still today many parts of the fortress are hidden by the lava and by the construction on top of it, such as the defensive barrier which is called "under the Castle". Only recently, following restoration works carried out from 1988 to 2009, the door called of Salt, or of Sun, together with its elegant staircase, have been unearthed. This door established a strong visual connection with the horizontal level of the water and a direct link to the underlying beach on the weapons level.

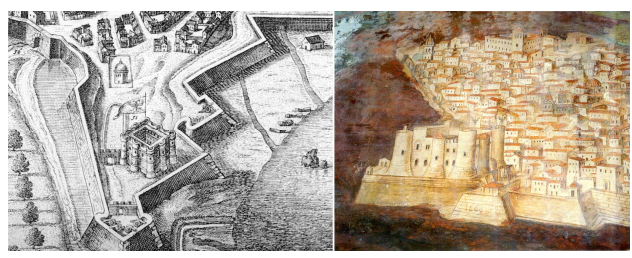

Fig. 5. The Ursino Castle at the end of the sixteenth c. from a perspectival map by A. Stizzia, 1592 (revised by P. Mortier, Amsterdam, seventeenth century) and after the eruption of Etna in 1669 (in a particular of the painting in the sacristy of the Cathedral of Catania).

The Ursino Castle's archetype is found in the Roman castrum, from which all of the following castles came from and is a fundamental reference of fortified architecture for both the East and the West. The Cistercian and Arabian architectural influences will insert and mix themselves with this model, with a fusion of elements that are so different from both a chronological point of view as well as a conceptual one. They mixed the squared plan of the Roman castrum to the cross vaulted ceiling of Gothic origin, or more properly of Cistercian origin. This is a fundamental architectural reference in the plans of the castles of the crusaders, from which Frederick II certainly had direct experience. ${ }^{7}$

This would all have also had a historical foundation as well, seeing the known close relationships between the Cistercian monks and the military members of the Holy Land, particularly the Templar Knights ${ }^{8}$. The Ursino Castle clearly exhibits the "Levantine" soul, or rather, the architecture of the crusaders' castles in the Holy Land, which were able to perfectly combine the monastic architecture with the building needs of the military. This was a construction concept 
that Frederick II became familiar with together with his court, officials and architects. The political events in the Holy Land drew him nearer to observe directly the large castles that the crusaders had built in Siria and Palestine. His interest and knowledge was also strengthened by the fact that the Frederician crusade was friendly towards the Islamic world and because men from the Islamic culture were called to his court. The architectural influence of the Arabic-Umayyad castles $^{9}$, in which the Roman-Byzantine and Persian expertise had merged throughout the centuries, has been supported by numerous studies.

Going from the Byzantines to the Arabs, even the castles that the Umayyads erected don't distance themselves from this Roman model: a square plan, or similar, with round towers in the corners and walled dividers. The living quarters were directly set against these dividers to create just as many buttresses (Fig. 6).

The similarities between the castles built in the Jordan and Syrian deserts during the eighth century and the Catanese monument are striking. This is demonstrated by a closed planimetry with an internal courtyard, the stereometric architectural volume, and the layout of the architectural system based on the geometry of the square and the circle. The layout used in the Ursino Castle of Catania is very similar to the Qasr al Kharanah in Jordan, built in the eighth century AD.

In terms of the Catanese fortress, Giuseppe Samonà underlines the strong local Arab influence that predated the travels to the Holy Land. This intuition was later supported by Stefano Bottari. It is based on the observation that the Swabian military architecture didn't represent the same stylistic homogeneity and a profound difference is evident between the Sicilian and those from Europe. These last present significant contrasts between light and shadow, creating a different spatial layout. It can be supposed that the local Arab influence in the Sicilian Swabian constructions is independent from that obtained in the Holy Land.

The Castrense-Catanese architecture faithfully expresses the learnings of the Frederician multiethnic court that had fully understood how to ab- sorb and blend the most varied influences inherited throughout the course of the centuries (Fig. 7).
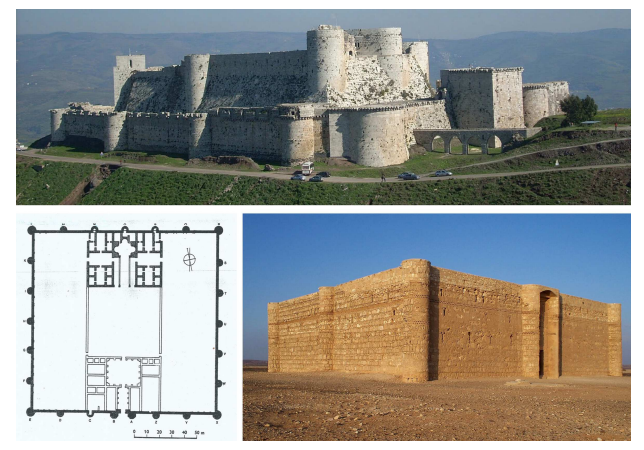

Fig. 6. Above: The Castle of the Knights (1099 A.D), Syria (https://it.wikipedia.org/wiki/Krak_dei_Cavalieri). Below: map of the fortified Palace of Mshatta, c.750, Jordan (https://it.wikipedia.org/wiki/Krak_dei_Cavalieri). Below-right: Castle of Qasr al-Kharana (eighth century AD), Jordan (https://it.wikipedia.org/wiki/Qasr_alKharana).
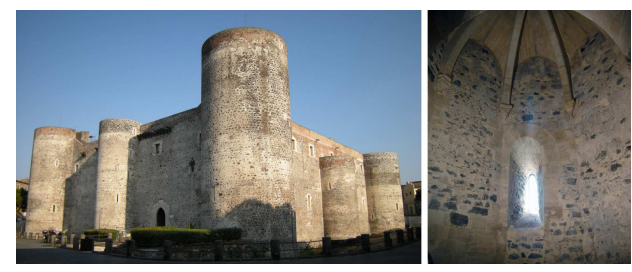

Fig. 7. Ursino Castle: angular view of the external facades and space covered by cross vault on corbels (http://www.icastelli.it/it/sicilia/catania/catania/castelloursino-o-svevo-di-catania).

\section{The Castrum Jacii, a natural-anthropic monument}

The stretch of Ionian coast north of Catania, known as the Riviera of the Cyclops, is a location of rare beauty, that unites natural, geological, historical, mythological, archaeological and architectural significance in an unicum of ancient origins.

It's a wild environment that always attracted man, so much so that it became an ideal location for famous poets to use as the scenery of mythological events ${ }^{10}$. In defence of this coast, that was the location for many struggles and conquest attempts, the Castle of Aci still towers to- 
day near the area where the sea town of Aci Castello stands.

The first evidence of a possible encastellation are referenced during the Byzantine resistance against the Muslim invasion (Amari, 1880-1881, p. 395), although many scholars tend to date the construction of the castrum to 1071-1081. The lack of documentation and of well defined construction elements leave ample room for doubt as many underline. Giuseppe Agnello in fact attributes the construction of the castle to the Frederician activities (Agnello, 1961, p. 387).

The layout underwent many adjustments and adaptations during the years to reinforce its outstanding military function and later to convert it to a residential function. This was up until its downfall which reached its culmination during the definitive disarmament of the structure and its reconversion in a prison by the Borbone government. The castle, having been renovated numerous times, is currently used as a museum and exhibition space. Various transformations, adjustments, but also violent destructions and rebuilding have deeply altered the fortified system, which today presents itself as a not easily legible palimpsest.

The element that most characterizes its mysterious charm is the entangled alternating between natural and anthropic elements. Empty spaces and massively full spaces, natural and artificial cavities, shapeless masses and squared blocks are subsequently placed with continuity, giving it an aspect of both strength and beauty. Widening our view even further, it is also the undefined relationship with the blue waters of the sea, from which it starkly separates itself with its black mass, but into which disappears with its cliff sinking under the water's level.

The contrasting relationship between the solidity of the lava and the fluidity of the sea's waters is the signature identity of the entire coast line on which the Castle of Aci sits.

From a geological point of view it is mainly constituted by magmatic underwater rocks which effused during the initial phases of Etna's activity roughly half a million years ago. They can currently be admired as they are above the water level due to the constant rising which has affected the lower south-eastern slope of Etna over the last hundreds of thousands of years.

Right above the most monumental of these inaccessible rocks, sustained by a single natural platform, the castrum strategically stands out. It is of the same rocky nature as the volcanic coast from which seems to flow, with an extraordinary geometrical-material naturalness.

This picture of rare scenic beauty emerges in a wide part of the iconographic documentation of the castle. The sources from the sixteenth and seventeenth century exult the role of the impregnable fortitude. We can refer back to the description, for example, from Spannocchi (1596) (Giuffrè, 1980, p. 38) or to the plans and axonometric depictions of Negro (1640) (Negro, Ventimiglia, 1640, pp. 145-146). Progressively though, the cultured travellers of the Grand Tour left written testimony and sketches of the site that were much more orientated towards the naturalistic peculiarities. Among these are the landscape paintings of Jean Houel (1770-1779), the etchings published by the French editor Abbé de Saint-Non (1781-1786), and the pencil drawing by the landscaper Christoph Heinrich Kniep (1787), who came to Aci Castello together with J.W. Goethe (Fig. 8).

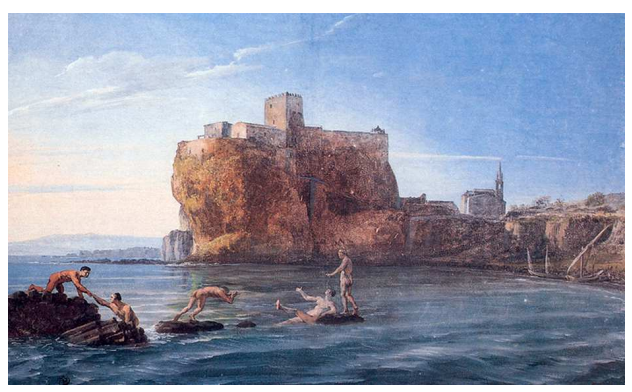

Fig. 8. The Castle of Aci in the depictions by the travellers of the Grand Tour. Above: J. Houel, 1782 (VV.AA. (1989). La Sicilia di Jean Houel all'Ermitage Sicilcassa. Palermo. p. 128).

These representations, just like those that came after, up to the photographic, cinematographic, literary and pictorial which are attributable to the second half of the last century, speak of an imposing, wild landscape. This is a very different 
image from the current one, which is significantly contaminated by the heavy urbanisation that has irreversibly modified the facies of this coastal environment.

An environment where only the castrum Jacii seems to still resist in its role of protector of the original impregnable beauty (Fig. 9).

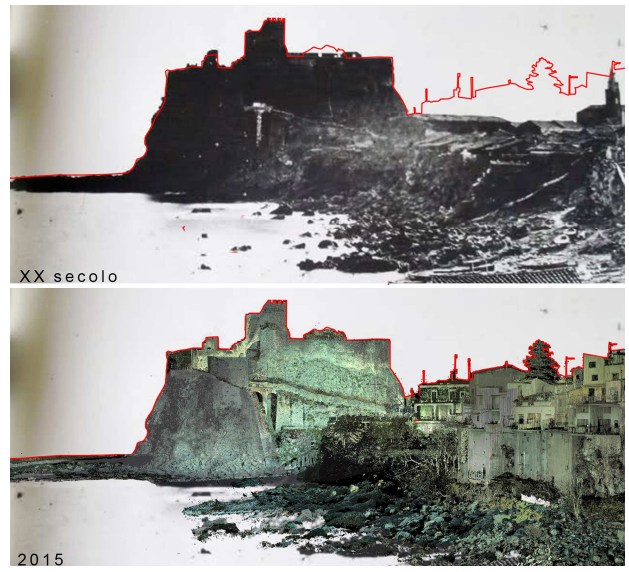

Fig. 9. Evolving relationship between the Castle and the town of Aci. Top: elaboration in photograph of the 1900s. Bottom: view of the point cloud model of the current configuration (Mobile mapping survey, Survey and Representation Laboratory, Kore University of Enna).

A new consideration, aimed at activating the most effective preservation and enhancement strategies must attentively evaluate the monument-landscape relationship (Fig. 10). On a closer scale, it becomes evidently necessary to take into consideration the entire massive cliffcastle system, even planning delicate and challenging stabilising and safety interventions of the coast which has been currently classified as an area of high risk and danger by the Hydrogeological Structure Plan of the Sicilian Region.

\section{Conclusion}

The study of all three coastal fortresses -which are so close and interrelated, yet so different among each other- aimed at reading the landscape, both historical and current, which nourishes in itself the most characteristic aspects of the defensive monuments on the water. In this direction, it was also crucial to give life to a never-ending hermeneutic cycle to those significant and productive interpretations that must be examined as evolutionary processes and historical documentation.

This allows for more extensive reflection. Our intervention is crucial as it is aimed at standardising knowledge processes that have to be sanctioned by a set of rules that must be shared and regulated by a universal document. In compliance with the European Landscape Charter, it can be recognised as a Defence Charter and must be intended as an instrument of cultural elevation and respect for the intrinsic values, aiming to give new life to the numerous, ancient fortifications that exist in our territory and to safeguard the landscape inseparably connected to them.

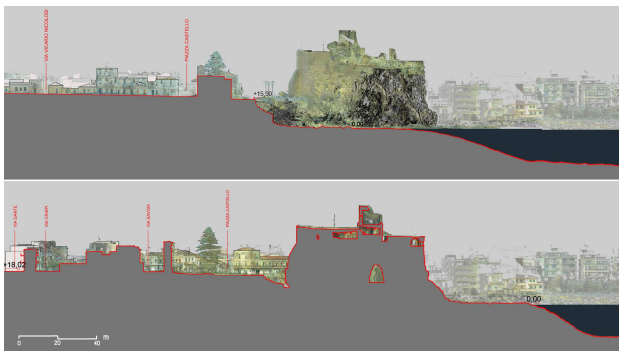

Fig. 10. The Castle of Aci in the anthropic-natural landscape (Mobile mapping survey, Survey and Representation Laboratory, Kore University of Enna).

\section{Notes}

${ }^{1}$ Author contributions: G. Taibi: sections 1, 5; R. Valenti: section 2; T. Patanè: section 3; M. Liuzzo: section 4.

2 Words spoken by Piero Gazzola during his inaugural speech for the convention on Le opere fortificate nel paesaggio e nel contesto urbano (Naples, 1969).

${ }^{3}$ Built at the request of Frederick II between 1232 and 1240. For historical sources refer to an extended bibliography, of which only some texts are sited in this reference bibliography.

${ }^{4}$ L. Dufour looked after part of the records of the section related to the publication catalog of the Beneventano del Bosco (1995). The record cited refers to the representation of G.F. Foresti 
of Bergamo in Supplementum Chronicarum, $1^{\circ}$ ed. latin, Venice 1483. Xylograph $5 \times 5.5 \mathrm{~cm}$.

${ }^{5}$ S. Russo, the file of L'Antiche Siracuse di D. Vincenzo Mirabella e Alagona dedicate alla S.C.R.M. del re Filippo III Nostro Signore, in Beneventano del Bosco, 1995, pp. 41-49.

${ }^{6}$ The reference is the Carte on Plan Géométral fait à vol d'oiseaude l'antique ville de Syracuse et de ses Environs from a drawing by Chatelet in R. de Saint-Non, Voyage pittoresque de Naples et de Sicile, t. I, Paris 1781-86, tav.109, Etching, 29x38 cm. (Beneventano del Bosco 1995, p. 89).

${ }^{7}$ Recent archaeological digging campaigns have identified similarities between the Frederician castles and the castles of Kawab and Belvoir in Galilee and Saramanda Kolomes in Pafos.
8 The studies of Enlart, Bertaux, Haseloff, Agnello and Kroning also link the Frederician castles to those of the Holy Land crusaders and Cyprus.

${ }^{9}$ The Umayyads felt the necessity to build their palaces outside of the city to demonstrate to the Beduin chiefs that they too were Beduins, even though they remained the uncontested kinds of the new empire. They built over thirty castles, mainly in Jordan.

${ }^{10}$ Poets such as Omero, Virgilio, Euripide and Teocrito placed at this location stories such as the myth of Odysseus and Polyphemus and also that of Acis and Galatea. In more recent times, it has also been a location for, among many others, the novel I Malavoglia by G. Verga, and the film La Terra Trema by L. Visconti.

\section{Bibliography}

Agnello, G. (1980). L'architettura civile e religiosa in Sicilia in età sveva, Roma.

Amari, M. (1880-81). Biblioteca arabo-sicula, Torino-Roma, vol. I.

Beneventano del Bosco barone di Monteclimiti, P., ed. (1995). Siracusa urbs magnificentissima. La collezione Beneventano di Monteclimiti, Electa, Milano.

Cadei, A.; Stefano, C.A. Di. (1995). Federico e la Sicilia, dalla terra alla corona, Ediprint, Palermo.

Giuffrè, M. (1980). Castelli e luoghi forti di Sicilia.XII-XVII secolo, Vito Cavallotto, Palermo.

Muscarà, P. (1982). Il Castello di Aci nella leggenda e nella storia, La Celere, Catania.

Negro, F.; Ventimiglia, E.M. (1640). Atlante di città e fortezze del Regno di Sicilia 1640, Aricò, N., ed., Sicania, Messina, 1992.

Pagello, E. (2004). "Siracusa”, in Magnano di San Lio, E.; Pagello, E., eds., Difese da difendere. Atlante delle Città Murate di Sicilia e Malta, Officine Grafiche Riunite, Palermo, pp. 167-170.

Platania, F. (2008). Viaggiatori nelle terre di Ulisse. Acicastello-Acireale-Catania-Etna-Taormina, Bonanno, Acireale-Roma.

Russo, S. (1992). Siracusa medioevale e moderna, Arnoldo Lombardi Ed., Palermo.

Seigneur de Caumont Nompar. (1858). Voyaige d'oultremer en Jhérusalem (1418), publié par le Marquis de La Grange, Paris, 1 vol. 8.

Terranova, C.P. (1993). “I Castelli dell'Etna”, in Etna. Il vulcano e l'uomo, Giuseppe Maimone, Catania, pp. 245267.

Voza, C. (1994). Guida di Siracusa, ERRE Produzioni, Siracusa.

VV.AA. (2001). Castelli medievali di Sicilia. Guida agli itinerari castellani dell'isola, Regione Siciliana Centro Regionale per l'Inventario la Catalogazione e la Documentazione dei Beni Culturali e Ambientali. Palermo. 